\title{
Arbor
}

\section{Los Argumentos de la Ciencia en la Creacion Literaria}

\section{Ángel Martín Municio}

Arbor CLXXIX, 706 (Octubre 2004), 443-472 pp.

En este examen que hoy comienza de la proyección social de la ciencia, me parece que ocupa un lugar importante el uso que las diferentes formas de creación literaria han llevado a cabo del hecho científico y tecnológico. Si la literatura como circunstancia cultural relevante forma parte de la calidad de vida del hombre, no habrá obstáculo que oponer a que, de esta manera, también la ciencia contribuye a la difusión de su significado social. De múltiple y variada naturaleza pueden ser las relaciones que se establecen entre la ciencia -sus conceptos, sus ideas y su expresión-, de un lado, y la creación literaria, de otro.

Relaciones ciencia-literatura que pueden mostrar uno de sus extremos en el hecho de que ciencia y científicos comparten el lenguaje con otros escritores. El lenguaje literario, sin embargo, en su creatividad subjetiva, puede llegar a ser un fin en sí mismo; en tanto que el lenguaje de la ciencia es instrumental y carente de ambigüedades para el logro de algo adicional y objetivo; sus descripciones y cualidades son también distintas. En el primer caso se ha dicho que la literatura es la conciencia que el lenguaje tiene de ser eso, lenguaje; de tener una existencia independiente. La literatura puede hacer del lenguaje un ingrediente ingrávido, sin otro significado que sí mismo. La ciencia utiliza el lenguaje como código de referencia para significar algo más ajeno a él: un hecho, un significado o una verdad. Ambas, en cualquier caso, buscan nuevas visiones de las cosas.

Y como representación del otro extremo bien pudiéramos escoger las confluencias formales que nos señaló Octavio Paz, hace un cuarto de siglo, en sus ensayos recogidos bajo el título de "Corriente alterna»: "Hay 
más de una semejanza-dice Paz-entre la poesía moderna y la ciencia. Ambas son experimentos, en el sentido de prueba de laboratorio: se trata de provocar un fenómeno por la separación o combinación de ciertos elementos, sometidos a la presión de una energía exterior o dejados a la acción de su propia naturaleza. El poeta no postula ni afirma nada de antemano.....su actitud frente al poema es empírican.

En otro lugar, Paz llega a admitir que la posición del poeta no es muy diferente de la del hombre de ciencia. Este logra participar en la experiencia y, en ciertas ocasiones, forma parte del fenómeno y, en consecuencia, lo altera. Por lo que respecta a la poesía moderna, añade: " $E l s u$ jeto de la experiencia es el poeta mismo: él es el observador y el fenómeno observado. Su cuerpo y su psique, su ser entero, son el campo en donde se operan toda suerte de transformaciones. La poesía moderna es un conocimiento experimental del sujeto mismo que conoce. La poesía es un saber y un saber experimental».

Idea de la que ya participó Zola en el texto programático de su obra "La novela experimental» (1880), en la que, al adaptar las innovaciones que Claude Bernard había descrito en "La introducción al estudio de la medicina experimental" acerca de la experimentación y la prognosis, justificaba sus esquemas y procedimientos novelísticos y reivindicaba para la novela los criterios de verificación y predicción que se introducían en la Medicina. Idea compartida, ya en 1939, por Bertold Brecht en su obra "Sobre el teatro experimental".

Pero, quizás, el mayor interés de este tipo de tratamientos formales en el establecimiento de la coherencia ciencia-literatura, es el de poder celebrar la universalidad del pensamiento. Universalidad que Octavio Paz explica de esta manera: ".....la estructura física de los átomos y sus partículas es una estructura matemática, una relación. No es menos extraordinario que esa estructura pueda reducirse a un sistema de señales y que sea, por tanto, un lenguaje. La facultad de hablar es una manifestación particular de la comunicación natural; el lenguaje humano es un dialecto más en el sistema lingüistico del universo ..."

Y si en este sentido, el mismo Paz ha expresado metafóricamente que el poeta participa en los asuntos de la ciudad; toda una colección de ejemplos nos dan fe de este tipo de integración del conocimiento. Así, químicos como Davy, Borodin y Khachaturian, cultivan la poesía o la música; Madariaga y Spencer ejercieron la ingeniería; Zane Grey fue dentista; Chaikovsky abogado; y Ansermet matemático. Dualidad que aunque se refiera a una múltiple actividad personal, refleja una comunicación -una 


\section{Los Argumentos de la Ciencia en la Creacion Literaria}

unidad mental, si queremos-, cultural en todo caso, biológica con toda seguridad, entre las diversas expresiones de la creatividad. Así, con motivo de la exposición "L'àme au corps" que se presentó hace pocos años en el Grand Palais de París, su comisario Jean Pierre Changeux, director del laboratorio de neurobiología molecular del Instituto Pasteur, escribió: "El artista y el científico pretenden lo mismo; hacer visible el mundo existente». Más aún, Dostoevsky llegó a decir: "Yo tengo mi especial visión sobre la realidad en el arte; lo que la mayoría llama fantástico y excepcional, no significa para mí sino la mismísima esencia de la realidad».

A este respecto, Ernesto Sábato, en su "Itinerario» asegura: "La literatura, esa híbrida expresión del espíritu humano que se encuentra entre el arte y el pensamiento puro, entre la fantasía y la realidad, puede dejar un profundo testimonio de este trance y quizá sea la única creación que pueda hacerlon. Literatura, pues, como buscadora de comunicación y de completitud de pensamiento. $\mathrm{Y}$ a ello se refiere también el mismo Sábato cuando afirma: "En el momento mismo en que las ciencias fisicomatemáticas me acababan de salvar, empecé a comprender que no me servían: eran un refugio en medio de la tormenta, pero nada más, aunque nada menos que eson. Contrastes, pues, incluídos en los relatos de algunos escritores creativos.

Y aunque no haya razones epistemológicas para dejar de admitir la relación recíproca entre ciencia y literatura, tampoco cabe pensar en una reversibilidad total. Yo creo que, al menos hasta ahora, la capacidad y la inspiración de la ciencia para inducir y dar forma a la creación literaria son superiores a la aptitud de la literatura para requerir o inspirar la creación científica. En el seno de cuyas relaciones cabe preguntarse ¿cómo las figuras, metáforas y mitos, comparten el discurso común de la creación literaria y científica?, ¿cómo el creador literario se adentra en las hipótesis, los descubrimientos y los hechos de la ciencia? Puede que tenga que ver con ello lo que se narra en una sugestiva novela de nuestro tiempo, cuando dos amigos de edad madura -como de edad tardía los refiere el autor-emprenden juegos demasiado peligrosos; y a sus personajes -cuenta la novela de Landero- "la primavera los sorprendió examinando los misterios del arte y de la ciencia. Gil-uno de ellos-preguntó como podía saberse el punto exacto del progreso en que se encontraba el mundo. Gregorio, que había previsto la pregunta, leyó en la libreta que habia un lugar medio secreto donde iban los artistas con sus obras, los científicos con sus inventos, los filósofos con sus teorías, los médicos con sus remedios y los oradores con sus discursos. Un lugar donde se vendía, se compraba, se cambiaba y se daba a conocer, como un gran Mercado de 
la Inteligencia o Lonja del Progreso". Y en ese ambiente surgió la pregunta: "¿Cuál es la diferencia entre el científico y el poeta? Bueno, la ciencia si miente pierde su valor, y el poeta siempre dice la verdad aunque mienta. Lo que se dice en verso nadie lo puede contradecir en prosa, porque no forma una opinión sino un designio. Lo que es bello es también verdadero, ya lo dijo Platón. Y luego está la libertad. Los artistas no tenemos amos".

A pesar de esa unidad mental, nos enfrentamos con visiones, pues, de dos mundos diferentes. En el de la literatura se ama y se odia, se triunfa y se humilla, se alegra o se sufre, hay sosiego o desesperanza. En el de la ciencia, se fijan sus doctrinas y sus ideas a las concepciones del mundo por medio de un lenguaje que no es un simple utensilio neutral. Mundos diferentes que no dejan por ello de participar de una base común dentro de la historia cultural y social. Mundos diferentes que cambian frecuentemente sús papeles. También en el de la ciencia -de lo que hay muchos ejemplos- se triunfa y se alegra y hay esperanza. También el de la literatura se incrusta en el ambiente producido por las corrientes científicas del mundo físico y los avances tecnológicos.

Dentro de esta interacción ciencia-literatura, no son extraños los casos en los que la ciencia subyace en la literatura de una manera sutil, inapreciable algunas veces al examen crítico. En cualquier caso, el análisis de la huella que la ciencia ha ido dejando en la literatura puede sistematizarse según la naturaleza del hecho científico mismo, el género literario, la época de los autores, etc. y, sobre todo, por la contribución de la aportación científica -su rigor y su lenguaje- al contenido global de la creación literaria.

La contribución, pues, de las descripciones científicas a la armazón creadora puede tener un peso diferente, tanto desde una consideración cuantitativa como cualitativa. De esta forma, seguramente, la contribución más somera es la que se muestra a manera de decorado natural que da fondo a la trama literaria. A su lado, nos encontramos con ideas científicas, más o menos desarrolladas, formando parte de los pormenores de la trama. Los temas científicos que en ella intervienen se mueven desde los propios de los dominios de la física, la biología o la medicina, hasta los de la psicología del hombre. Entre ambas situaciones se encuentra todo un gradiente de contribuciones científicas al conjunto del hecho literario, que tienen, a su vez, como representantes más significativos, la biografía y la novela científica, la que saca partido de las teorías y los resultados de la ciencia en el planteamiento y solución de la armazón novelesca; y 


\section{Los Argumentos de la Ciencia en la Creacion Literaria}

que tiene en la novela de ciencia-ficción una forma singular de narrativa que, al ir más allá de los hechos reales del momento, explota las perspectivas imaginativas de la ciencia moderna. Ficción en los protagonistas y sus peripecias; ficción en el mundo circundante de los personajes; y ficción, sobre todo, cuando la ciencia rehusa discriminar entre lo posible y lo imposible, y, a la vez, intenta adivinar las imágenes del futuro. Es cierto que durante algún tiempo la novela de ciencia-ficción no ha gozado de los favores de la crítica literaria, hasta el punto de recordar en su descrédito aquel castigo que recoge la primera sátira de Perseo: "A esas gentes por las mañanas les castigo con un edicto y por la tarde les hago leer una novelan. Su carácter literario se puso en duda, y de ella, como de ninguna otra, se puede afirmar que es el género de la libertad; libertad de contenido y libertad de forma. Género por naturaleza polifacético y mudable. La única regla que cumple universalmente es la de transgredirlas todas". Sin embargo, no puede ponerse en duda la existencia de un equilibrio dinámico ficción-realidad, que se ha desplazado ultimamente a gran velocidad en la dirección de la realidad, al hacer verdad fantasías de no hace muchos años. Cada vez, la utopía de la ciencia-ficción y, por tanto, su literatura, se va convirtiendo en hechos de la vida ordinaria, ya fuera en la exploración del espacio, los intríngulis de la evolución o la clonación de animales, y que, por tanto, pasan a convertirse en la narración de la misma novela científica. Dicho de otra manera, los argumentos mismos de la ciencia-ficción han ayudado a crear los futuros argumentos de la ciencia en aquellos casos en que la ciencia imaginaria se había basado en una ficción intelectual.

Para darnos una ligera idea de este desplazamiento del equilibrio ficción-realidad, echemos una ojeada a lo que escribió un escritor, hombre de ciencia, Pio Baroja, en "El árbol de la ciencia». En uno de los ágiles diálogos de la vida estudiantil universitaria de la época se cruzan estas sentencias:

- Ya la Ciencia para vosotros -dijo uno de los estudiantes-, no es una institución con un fin humano; la habéis convertido en un idolo.

- Hay la esperanza de que la verdad, aún la que hoy es inútil, pueda ser útil mañana-replicó otro-.

- ¡Ba!, ¡utopía! ¿Tú crees que vamos a aprovechar las verdades astronómicas alguna vez?

- ¿Alguna vez?, ¡las hemos aprovechado ya!

- ¿En qué? 


\section{Ángel Martín Municio}

- ¡En el concepto del mundo!

- Está bien; pero yo hablaba de un aprovechamiento práctico, inmediato.

$\mathrm{Y}$ en otro lugar se refiere a algunos pasajes bíblicos, y, entre otros, el siguiente: "Tú habrás leído que en el centro del paraiso había dos árboles, el árbol de la vida y el árbol de la ciencia del bien y del mal. El árbol de la vida era inmenso, frondoso, $y$, según algunos santos padres, daba la inmortalidad. El árbol de la ciencia no se dice cómo era; probablemente sería mezquino y tristen.

Nadie pensará hoy que la ciencia no se aprovecha y, mucho menos aún, que la ciencia es mezquina y triste. Si, de un lado, hay que coincidir con el filósofo cuando asegura que la Naturaleza sólo es bella para una inteligencia que la ve y la contempla; de otro lado, no hace falta insistir demasiado para darnos cuenta de todo lo que nuestra presente calidad de vida debe a los hechos de la ciencia y la tecnología.

La naturaleza fue siempre el escenario de las ideas morales y religiosas, y las plantas y las flores han sido protagonistas del teatro de la humanidad en todas las épocas.

En la literatura clásica "De rerum natura" es la primera gran obra de poesía, anticipación científica de posteriores observaciones y descubrimientos. Es el poema de la materia, aunque se nos advierte desde sus comienzos que la verdadera realidad de esa materia consiste de corpúsculos invisibles;.... que el vacío es tan concreto como los cuerpos sólidos. Otro ejemplo, y desde antiguo, de la concepción enciclopédica de ciertas obras literarias son "Las metamorfosis". El mundo poético de Ovidio está hecho de atributos y de formas que delimitan la naturaleza de los ingredientes del mundo, las plantas, los animales, las cosas y las personas. La "Historia natural" de Plinio es, de un lado, una fabulosa compilación de datos de la anatomía y la botánica comparadas, de los metales y las piedras preciosas, de la geografía y las bellas artes. Pero, a la vez, la erudición se mezcla con la fantasía cuando cuenta sus sentimientos cosmológicos o habla del misterio de las formas y las ideas.

Especial protagonismo literario de las plantas supuso la gran obra de Erasmus Darwin, a finales del siglo XVIII, titulada "The botanic Garden"; sobre todo su segunda parte "Los amores de las plantas". Erasmus fue abuelo de Charles Darwin, médico, hombre de ciencia e inventor famoso y promotor de las nuevas tecnologías durante la revolución indus- 


\section{Los Argumentos de la Ciencia en la Creacion Literaria}

trial. En 4376 versos, Darwin pormenorizó los amores de las plantas vestidos a lo humano y acogidos al rigor de las descripciones sexuales de Linneo. Mostró, personificados, sus actitudes y enredos, llenos de ironía y humor; popularizó la seriedad de los planteamientos científicos mediante descripciones frívolas, llenas de ingeniosos episodios mitológicos. Un año después de su muerte apareció su poema "El templo de la naturale$z a \prime \prime$, en el que rastrea la evolución de los seres vivos, desde los microscópicos hasta el hombre. Evolucionista antes de su tiempo, diseñó un escenario evolutivo un siglo antes de que pudiera ser aceptado. No deja de ser, sin embargo, significativo que el verso final de "El jardín botánico" sea: "Y los amores pueden reirse de todo menos de las leyes de la naturaleza».

Muy frecuentes son los relatos que se desarrollan en los escenarios naturales, cuya descripción ha llenado multitud de páginas de todas las literaturas. Así, entre las encinas y alcornoques de la Mancha o en los jarales de Sierra Morena transcurrieron muchos de los episodios y aventuras de don Quijote y Sancho. Un gran maestro de la botánica española, Luis Ceballos, en su "Flora del Quijote», reúne todas las acciones de las que las encinas fueron testigo: de una encina, don Quijote desgarró una rama para sustituir su lanza; en el tronco de una desmochada encina se sienta el pastor Antonio para tocar el rabel y entonar su amoroso canto; emboscado en la floresta encinar junto al Toboso esperan la noche para que vaya Sancho a entrevistar a Dulcinea.

En una reciente narración, y como simple ejemplo, se puede leer: "Cosímo estaba en el acebo.... miraba al mundo desde el árbol. El acebo estaba junto a un olmo; las dos copas casi se tocaban. Desde el olmo, buscando siempre el lugar donde una rama pasaba a un codo de las ramas del otro árbol, se pasaba a un algarrobo, y luego a una morera.... Cosímo se dejó caer sobre las hojas oscuras de una planta recien importada de las colonias americanas, la magnolia, en cuyas ramas negras brotaba una carnosa flor blanca...". Lo importante es que por el jardín paseaba la Generala con el Barón, iban del brazo y miraban los rosales....era el Barón de Rondó, quien, de niño, en un arrebato de ira, trepó a los árboles y, de árbol en árbol, caza, lucha, estudia y corteja. Se trataba, a no dudarlo, del "Barón rampante", una de las obras de Italo Calvino en la que, como en "El caballero inexistente" y en "El vizconde demediado", nos presenta visiones de la naturaleza entremezcladas con historias fantásticas.

Aparte de este telón de fondo sobre el que se mecen personajes y sentimientos, las plantas han protagonizado desde la prehistoria leyendas, 
mitos y magias. Todos ellos, reunidos, forman la "Botánica oculta" de Juan Perucho.

Por lo que se refiere a la naturaleza animal, son numerosos los seres que han participado en el lenguaje literario. En su representación elegiré los insectos. Cuando Alicia, "Al otro lado del espejo", y el mosquito, que le susurraba al oído, platicaban sobre los nombres de los insectos -el Tábano, la Libélula, el Dragón-, el mosquito preguntó a la niña: "¿de qué sirve que tengan nombre si no responden cuando se les habla por su nombre?»" En ese momento faltaban varias docenas de años para que los creadores, al estilo de Rubén y Juan Ramón, dieran un nuevo paso hacia la confluencia entre la belleza y la verdad: "aún la verdad poética podría ser bella mentira", escribió Juan Ramón. En Rubén, "la reina Mab, en su carro hecho por una sola perla, tirado por cuatro coleópteros de petos dorados y alas de pedrería, caminando sobre un rayo de sol, se coló por la ventana....".

El poeta crea, descubre y expresa la belleza. Si, además, canta la belleza de lo invisible y manifiesta la verdad oculta que revela la ciencia, de forma rigurosa y precisa, la poesía hibrida belleza y verdad. Es el caso de los insectos como realidad poética -poesía y ciencia, intuición y razón- en Dámaso Alonso. En su presentación del poema "Los insectos" aclara: "Altas horas. La ventana abierta. Y sobre la lámpara, sobre mi cabeza....inmensas bandadas de insectos;....duros, pesados coleópteros; minúsculos hemipteros saltarines; grotescos ortópteros, lepidópteros en miniatura; vivaces y remilgados dipteros; tenues, delicadísimos neurópteros $y$, como ojos, dos bolitas diminutas de un oro purísimo. Oh, mucho más bellas que lo que llamamos oro. Todos extraños y maravillosos". Que sabía muy bien lo que decía nos lo aseguran otros versos del poeta: "Oh, los sabios, la Ciencia, con mayúscula/ sí, sí, lo sé./ Mas sé mejor, mucho mejor, dejadme...". Sabía, en efecto Dámaso que una de las maravillas más extraordinarias de la observación biológica era el ojo compuesto de los insectos, con una estructura modular integrada por muchos cientos de omatidios, elementos visuales en forma de pirámides truncadas de cuya disposición regular resulta tanto la estructura hemisférica del ojo como el esquema preciso de proyecciones axonales hacia los ganglios ópticos. No tiene nada de extraño, pues, la admiración del poeta por estos ojos de los insectos:

"Me están doliendo extraordinariamente los insectos, porque no hay duda estoy desconfiando los insectos, de tantas advertencias, de tantas patas, cabezas y esos ojos, oh, sobre todo esos ojos....". 


\section{Los Argumentos de la Ciencia en la Creacion Literaria}

Ellos merecieron una elegía y, así fueron en ella los versos de Dámaso Alonso:

"Estabas en mi casa,

mirabas mi jardin, eras muy bello.

Yo te maté.

Oh si pudiera ahora

darte otra vez la vida,

yo que te di la muerten.

Dejando ya esta participación de la Naturaleza, adelantemos que los hechos de la ciencia - de la física, la biología o la psicología-intervienen en los argumentos de la creación literaria, de la novela, de la poesía e, incluso, del teatro.

Una de las novelas más famosas de nuestros días pone en boca de uno de sus personajes, justo al comienzo de la narración: "Fue entonces cuando vi el Péndulo. La esfera, móvil en el extremo de un largo hilo sujeto de la bóveda del coro, describía sus amplias oscilaciones con isocrona majestad. Sabía, aunque cualquiera hubiese podido percibirlo en la magia de aquella plácida respiración, que el periodo obedecía a la relación entre la raíz cuadrada de la longitud del hilo y ese número d que, irracional para las mentes sublunares, por divina razón vincula necesariamente la circunferencia con el diámetro de todos los círculos posibles, por lo que el compás de ese vagar de una esfera entre uno y otro polo era el efecto de una arcana conjura de las más intemporales de las medidas, la unidad del punto de suspensión, la dualidad de una dimensión abstracta, la naturaleza ternaria de ð, el tetrágono secreto de la raíz, la perfección del círculon. También sabía que en la vertical del punto de suspensión, en la base, un dispositivo magnético, comunicando su estímulo a un cilindro oculto en el corazón de la esfera, garantizaba la constancia del movimiento. Era un artificio introducido para contrarrestar las resistencias de la materia, pues no sólo era compatible con la ley del Péndulo, sino que, precisamente, hacía posible su manifestación, porque, en el vacío, cualquier punto material pesado, suspendido del extremo de un hilo inextensible y sin peso, que no sufriese la resistencia del aire ni tuviera fricción con su punto de sostén, habría oscilado en forma regular por toda la eternidad. Rigurosa la descripción física con que se inicia "El Péndulo de Foucault». Pocos párrafos más adelante continúa el personaje: "El Péndulo me estaba diciendo que, siendo todo móvil, el globo, el sistema solar, las nebulosas, los agujeros negros y todos los hijos de la gran emanación cósmica, desde los primeros eones hasta la materia más viscosa, un sólo 
punto era perno, clavija, tirante ideal, dejando que el universo se moviese a su alrededor. Y ahora yo participaba en aquella experiencia suprema, yo, que sin embargo, me movía con todo y con el todo, pero no era capaz de ver Aquello, lo Inmóvil, la Fortaleza, la niebla resplandeciente que no es cuerpo, no tiene figura, forma, peso, cantidad o calidad; y no ve, no oye, ni está sujeta a la sensibilidad; no está en algún lugar o en algún tiempo, en algún espacio; no es alma, inteligencia, imaginación, opinión, número, orden, medida, sustancia, eternidad; no es tinieblas ni luz; no es error y no es verdad".

Y cuando este personaje, el personaje del Péndulo, pasaba revista a lo que Humberto Eco llama cementerio de cadáveres mecánicos, con el alma herrumbrada, puros signos de un orgullo tecnológico e intentaba esconderse y permanecer en el museo de antiguos objetos móviles; cuando tenía que ser astuto y lúcido, se dijo para sus adentros: "Animo, deja de pensar en la sabiduría. Pide ayuda a la ciencian. Nuestros clásicos, a su manera, ya lo resolvieron. Por algo, Calderón, en "La estatua de Prometeor, aseguraba:

"Pues, moralmente se viera, que quien da luz a las gentes,

es quien da a las gentes ciencian.

No se extrañaría el personaje del Péndulo, cuando correteaba por las galerías del museo que abrió la Convención para facilitar el acceso de las gentes a la ciencia y el arte. No se extrañaría, digo, si hubiera conocido este pensamiento calderoniano. Pienso que no, porque cuando en su carrera por la historia de la ciencia vio en aquellas galerias su imagen invertida en un espejo, exclamó: "Desde el medioevo árabe conocemos todas las magias de los espejos. ¿Valía la pena la Enciclopedia, el Siglo de las Luces, la Revolución, para afirmar que basta con curvar un espejo para precipitarse en lo imaginario?".

Nos encontramos, pues, de lleno en la participación de las ideas de la Ciencia en los pormenores de la creación literaria. De las ideas de la física -la velocidad, la gravedad, el tiempo, la incertidumbre-, de la biología -la fisiología y la neurobiología de la visión, por ejemplo-, de la psicología, etc.

Precisamente, por la falta de pesantez vuela el cubo de Kafka, en el cuento "El jinete del cubo", para recoger un poco de carbón; vuela el barón de Münchausen en sus aventuras. O cuando el Romeo shakesperiano asegura que se hunde bajo el peso del amor, el consejo de Mercurio 
no es otro que ya que te has enamorado, álzate con las alas que Cupido te preste. O cuando en "Cien años de soledad", García Márquez hace a sus personajes volar, levitar y atraer nubes de mariposas.

La obra de Leopardi, tan rica en todo tipo de imágenes físicas, lo es de manera singular cuando fantasea sobre la velocidad, en su "Zibaldonem, velocidad física o mental, y a la vista de los caballos gratísima en sí misma por la vivacidad, la energía, la fuerza, la vida de la sensación, le lleva también a asegurar que despierta una casi idea de infinito, eleva el alma, la fortalece.

La dualidad rapidez-lentitud ha sido con frecuencia figura de la creación literaria. Dos humoristas, distanciados sus relatos en un siglo, Tomás de Quincey y Fernández Flórez, el primero en el "Coche correo inglés", y nuestro escritor en "El hombre que compró un automóvil», ofrecen imágenes calcadas sobre el espejo del tiempo:

"Los enfurecidos caballos -los del coche correo, por supuesto- habian pasado un recodo del camino que ponía delante de nosotros la etapa final en que el choque habría de tener lugar y la catástrofe quedar sellada".

$\mathrm{Y}$ al cabo de un siglo podemos leer:

"....esta ausencia de la voluntad del hombre en los movimientos del auto los impresionaba más de lo que querían revelar. El frío del miedo corría por el cauce de sus médulas. De pronto, el industrial giró bruscamente a la derecha y en ese instante el camión se precipitó -acometió, sería más exacto decir-contra ellos».

La exactitud, como precisión léxica y como expresión de los matices más finos del pensamiento, tiene en Paul Valèry y en su personaje Monsieur Teste un ejemplo de matematicidad de la imaginación. Cuando Monsieur Teste paseaba por París, un amigo que le acompañaba relata su pensamiento y sus frases aparentemente incoherentes:

"Encuentro allí la ilusión de un trabajo inmenso que, de golpe, se me vuelve posible....Me da sensaciones abstractas, figuras deliciosas de todo lo que amo; del cambio del movimiento, de la mezcla, del fluir, de la transformación... ¿Negaría Vd que existen cosas anestésicas?, ¿árboles que embriagan, hombres que dan fuerzas, muchachas que paralizan, cielos que cortan el habla?".

Desde Heisenberg, la incertidumbre pertenece al lenguaje de la ciencia aristocrática al señalar que la naturaleza no pasa de ser sino síntesis 
de lo que el hombre es capaz de ver en ella; lo que ya dio pie a Unamuno para regocijarse con su presencia ya que-decía el- "es estúpida la fe sin sombra de incertidumbre y mucho más estúpida la incredulidad sin. sombra de dudan.

La incertidumbre es tảmbién una idea muy fructífera en las descripciones literarias, y así lo ha sido para la creación de "El ritmo de la vida", de Lyall Watson. El autor utiliza la idea, es decir, la dificultad con que se encuentra el método científico al llevar implícito el hecho de que el observador y el experimentador se encuentran fuera y son independientes de los objetos de su atención. Así es en la descripción de la novela: «El desear cualquier cosa, cambia inevitablemente la cosa que deseas". Y con estas bases describe el autor el estado actual de la cosmología, la evolución prebiótica, el origen de las partículas virales, la organización génica y la proliferación celular.

Esta misma idea caracteriza la visión del autor italiano Carlo Gadda, cuyas novelas -quizá por su formación intelectual mixta, literato, ingeniero y filósofo- pertenecen a ese género narrativo enciclopédico que conforma una red de conjuntos, cada uno de ellos condicionado por los demás. Cada mínimo objeto es para Gadda un vasto horizonte con un sinnúmero de descripciones y de detalles; para Gadda también conocer es insertar algo en lo real, y por lo tanto deformar lo real. Con estos presupuestos no es extraño que cada episodio sea un mundo heterogéneo y complejo, como lo es el hallazgo de las joyas robadas en uno de los capítulos de su obra "El zafarrancho aquel de via Merulana". De esta manera, cada piedra preciosa de cada joya tiene una historia geológica, una composición química y una fórmula cristalina; a lo que se une todo un cúmulo de referencias históricas y artísticas, usos y destinos y, por supuesto, de imágenes de la mente y el sentimiento.

Inevitablemente, la novela enciclopédica moderna no tiene más remedio que nutrirse del ambiente científico de la época. Y de esta manera ocurre en "Bouvard et Pécuchet" de Flaubert, "La montaña mágica" de Man, "La vida. Modo de empleo" de Perec, o en "Ulises" de Joyce, una de las últimas y mejores obras del simbolismo, en la que descubre las miserias y las dignidades de Ulises, viajante de comercio judio de Dublin. Sus penas, sus arrepentimientos y sus placeres, dan paso a descripciones científicas como en ciertos argumentos a propósito de las malformaciones congénitas, de la medicina obstétrica e, incluso, de la hibridación interespecífica. A modo de ejemplo, se habla de los fetos acardíacos, la agnacia de ciertos chinos sin barba a consecuencia de una unión defectuosa de 


\section{Los Argumentos de la Ciencia en la Creacion Literaria}

las protuberancias maxilares a lo largo de la línea media, a tal punto que una oreja podía oir lo que salía de la otra...los casos de nacimientos multigeminados, bispermáticos y monstruosos debido a uniones entre consanguíneos...las anormalidaades de los labios leporinos, marcas de nacimieneto, dedos supernumerarios, manchas de frutilla ....

El tiempo, tan de moda, ha sido narrado de mil maneras para explicar el curso y la mudanza de las pasiones. Ciencia y poesía, filosofía e historia, se han enfrentado con la temporalidad de los seres vivos. Ya San Agustín se preguntó insistentemente sobre esta palabra, tan sencilla y oscura, tan vulgar y profunda, ¿qué es el tiempo? Medimos el tiempo a su paso y aseguró: "el presente existe, pero no perdura y, en cambio, el pasado y el futuro tienen duración, pero no existencian. El tiempo procede del futuro y camina hacia el pasado, de lo que concluye San Agustín que rel tiempo viene de lo que no existe hacia lo que no puede alargarsen. Se dice, no obstante, que hasta el siglo XIX no se planteó, en ciencia y en filosofía, en toda su complejidad, el problema del tiempo. Dudas e interrogantes parecidas a propósito del tiempo llegan hasta nuestros días. Cuando, hace casi cuatro décadas, muere Besso intentando, hasta los últimos días de sus ochenta años, conciliar la irreversibilidad del tiempo con la relatividad general, su gran amigo Einstein escribió a la familia: "Para los fisicos convencidos, la distinción entre pasado, presente y futuro es sólo una ilusión por persistente que sean. Einstein solidarizó al hombre y al planeta en que vive con el cosmos; pero fue Darwin quien logró la solidaridad de la vida del hombre con la vida en el resto de la Tierra. Darwin vinculó su conocida teoría a la noción de un tiempo lento, evolutivo, que en el pensamiento de la época equivalía a natural, frente a la idea de cambio brusco, discontinuo, más vinculado a lo sobrenatural. Dos siglos antes de las observaciones fundamentales que dieron origen a las teorías de Darwin, se podía ya leer el párrafo siguiente: "La vida de todos los hombres constituye una historia que representa la naturaleza de los tiempos que fueron; $y$, por la observación de esta historia, un hombre puede vaticinar, casi a ciencia cierta, las cosas probables que están todavía por nacer y que reposan envueltas en sus semillas y en sus débiles orígenes". Puede que no sea fácil reconocer en este texto a Warwick, personaje shakesperiano del "Enrique $I V »$. No es difícil, de otro lado, espigar entre las bellas figuras que el autor inglés siembra abundantemente la idea del tiempo. En el acto tercero de "As you like it», Orlando y Rosalinda; amorosos, se preguntan ¿̈qué hora es en el reloj?; en la conversación se puede escuchar: "No importa que no haya reloj en el bosque para que el tiempo cuente; se puede hacer igual de bien registrando su marcha perezosa a suspiro por 
minuto y a gemido por hora». En el acto quinto de "Ricardo II", en el torreón del castillo, el Rey exclamó: "He abusado del tiempo y ahora el tiempo abusa de mí, pues ahora el tiempo me ha tomado por el reloj que marca sus divisiones; mis pensamientos son los minutos y mis suspiros son el tictac que marca la hora sobre mis ojos..."

Cela ha escrito bellas imágenes sobre el uso y los usuarios del tiempo. Hace un cuarto de siglo escribió en "Las compañías convenientes": "Llegar a la meta prevista cuando la vida se apaga, no nos puede ilusionar. No es menester llegar el primero a nada; es, por el contrario, de toda necesidad el llegar a tiempor. Y en una colección de ensayos conmemorativos del centenario de Marañón, Cela esculpió así la huella del hombre: "Don Gregorio derrotó al tiempo con el arma que más ama el tiempo: la constancia; en su vida, más importante que el tiempo que no se aprovechó, fue el tiempo que no se dilapidó, el tiempo que no se dejó perder. El perder el tiempo no supone tan sólo una pérdida de tiempo-que bien mirado sería lo de menos-, sino también una alteración de la conciencia, un derroche de la paz más íntima y, lo que es peor, una dejación de la fe en uno mismo; .... a fuerza de lavarse el alma, cada mañana, en los claros chorros del tiempo que, por usarlo con alegría se ve pasar sin congoja, fue un domador del tiempo, un árbitro de su propio tiempo. En su cigarral, $\mathrm{Ma}$ rañón tenía un reloj de sol, un reloj que no daba las horas, pero sí las contaban.

En esta sutil manera de entrever las imágenes físicas, hay que hacer mención de las imágenes de infinitud de Borges y del espacio-tiempo de Juan Ramón Jiménez.

Una situación excepcional de esta incursión de los argumentos de la ciencia, en particular de la biología humana, en el seno de la obra literaria, es la que viene marcada por la obra de Shakespeare. En sus aproximadas tres docenas de obras hay más de setecientas referencias a la medicina, preferentemente a la neurología. Argumento de rara utilización, que sobrepasa el conocimiento normal de un profano, aún en nuestros días. Más aún, en los dramas de Shakespeare, los puntos de vista médicos, los diagnósticos y tratamientos no fueron hechos por médicos sino por gentes llanas. Habrá que añadir que en la época aún no se había establecido la circulación de la sangre ni la función del corazón, y, por entonces, el alma se iba residenciando tan pronto en el cerebro como en el corazón o el hígado. Extraña por ello más sus conocimientos de la anatomía del cerebro, de la demencia y la senilidad, de los efectos del alcohol y de la sífilis, o de los poderes curativos o tóxicos de muchas plantas. Así, 


\section{Los Argumentos de la Ciencia en la Creacion Literaria}

Julio César, Otelo y Macbeth sufrían convulsiones, con sus funciones mentales y percepciones alteradas, diagnosticadas como epilépticas.

El Rey, en la "Vida de Enrique V»; Lear, en el "Rey Lear»; Polixeno, en el "Cuento de invierno", son ejemplo de caracteres seniles. Así, Lear pierde el juicio, seguido de la pérdida de los amigos y la traición de sus más cercanos; y desarrolla una psicosis, pérdida de contacto con la realidad, como consecuencia del gran estrés físico y emocional. Lear padece alucinaciones visuales como ocurre a los pacientes psicóticos con un fondo físico, en contraposición a las alucinaciones auditivas propias del fondo psicológico.

Los grandes bebedores y los alcohólicos, como Toby Belch en la "Duodécima noche", o el portero en "Macbeth", dan lugar a descripciones como las referidas al segundo cuando asegura: "La bebida, señor, produce estas tres cosas: sueño, orina y coloración de la nariz». O cuando Toby Belch comenta acerca de Andrew: "Si le abrieran encontrarian mucha sangre en el hígado". Ello indica que Shakespeare conocía los efectos crónicos del alcohol y el daño hepático y cerebral. Cientos de años antes de las explicaciones etiológicas de la hipercoagulación, Shakespeare pone en boca de Falstaff, en la segunda parte del "Rey Enrique IV", lo siguiente: "Esta apoplejía es, a mi entender, una clase de letargo....una especie de sueño de la sangre y un hormigueo de mil diablos...", debido -según Falstaff- a accidentes y perturbaciones del cerebro.

Alcohol y alcoholismo se han multiplicado en la literatura. "No era pintura, ni el color de la salud, ni pregonero del alcohol; era el rojo que brota en las mejillas al calor de palabras de amor o de vergüenzan, señalaba Clarín en "La Regenta». Y Miguel Angel Asturias, al poner sitio a la dicha humana, en "Papa verde", discurre: "...el alcohol sirve para la nostalgia que nos deje en el alma el huido instante feliz..."

Cambiando de tema, aún en el terreno de lo biológico, el héroe nonato de la novela, Cristóbal, en el imaginativo laberinto de Carlos Fuentes, medita sobre su origen y describe la evolución de su morfología: "El huevo de mi madre me espera en su escondite ...en su trono de sangre...me abren los brazos a mí, el campión, victorioso sobre los millones de soldados y soldaderas muertos en la carrera inútil por llegar hasta aquí donde yo estoy, calentito, ávido, triste, pidiendo posada. Un esperma para un huevo. Ya se enredó en sus raíces el Cristobalito, ya se encontró su destino... Yo soy mi propio escultor: me estoy haciendo a mí mismo, desde adentro, con materiales vivos, mojados, flexibles: qué otro artista ha contado jamás con diseño más perfecto que el de mis cinceles y mis martillos: las 


\section{Ángel Martín Municio}

células se desplazan al lugar preciso para construir un brazo: es la primera vez que lo hacen, nunca antes y nunca después, ¿̇me entienden bien? Nunca seré repetido".

Dentro de los argumentos biológicos, la neurobiología de la visión, en la poesía de Dámaso Alonso, llegó a penetrar en la estructura y en los aspectos evolutivos de los ojos de diferentes especies. Así, de esta manera:

"Gracias...porque mi ojo es perfecto, para mi, humano....

porque mis ojos crean, porque inventan la luz.....

Gracias por no tener los tres mil ojillos de una avispa; por no tener la cinematográfica visión de mosaico de un estólido saltamontes.

Para el hombre sus ojos son perfectos

¿para qué la acuidad meticulosa de la visión del ave?

Allá en su vuelo el aguila

aplica y cambia momentáneamente

sobre el fondo de su retina,

diversos filtros de luz coloreados, de finisima precisión:

en un instante elige aquel que le resalta

con mayor nitidez

en lo hondo del valle

la presa,.....

Sería divertido, quizá, por un momento ver cómo el anableps tetrophtalmus,

feliz pez que nada con exquisita elegancia....

tan delicadamente que la mitad inferior de su ojo avanza

sumergida, pero la mitad superior hiende juvenilmente el aire.

$A h$, la refracción del aire es distinta de la del agua,

.....tal un señor con lentes bifocales".

En cuanto a los tratamientos psicológicos, es bien conocida su abundancia en la creación literaria. Ernesto Sábato explora en "El túnel» el universo humano, al novelar el resquebrajamiento del alma y poner sobre el tapete la mezquindad, el amor, los tedios, la soledad y la incomprensión. Su protagonista persigue lo inalcanzable a través de esperanzas imposibles y de la lucha entre la razón y la intuición. Novela psicológica que llega a justificar los suicidas por felicídad, los asesinos por benevolencia, las personas que se adoran hasta el extremo de separarse para siempre y los delatores por fervor. Es la equivalencia científica del pleno desorden, la lejanía del equilibrio y la complejidad. 


\section{Los Argumentos de la Ciencia en la Creacion Literaria}

Ahondando en los estudios psicológicos, no hay más remedio que recordar aquel verso de Pessoa: "Cada uno es mucha gente». Y, con el, la variedad que resulta de una misma actitud o composición esencial. Muchos siglos antes, San Pablo, en una de sus Cartas a los Corintios, dice: "En el presente vemos confusamente en un espejo, pero luego veremos cara a cara. En el presente, parcial es mi ciencia, pero luego conoceré como soy conocido". Otro punto importante que merece recordar es el comienzo de la novela de corte psicoanalítico "Deseo de ser piel roja", cuando el autor, Miguel Morey, afirma y se pregunta: "Sin duda eres alguien, pero ¿quién?" Y como si aclarara la cuestión, continúa: "Por momentos, la imagen que te devuelve el espejo se asemeja en todo a un carboncillo escolar trabajosamente copiado. Son exactamente tus facciones -no puedes negarlo. Y sin embargo, es como si en ese retrato tan minucioso se hubieran deslizado algunos fallos de aprendiz: una cierta contradicción en el equilibrio de los trazos, la falta de brío de algún rasgo - como señales de un agujero pusilánime en el talento del dibujante, como una bruma inmiscuida en el brillo de la mirada. Te miras y te dices que sin duda eres alguien, que ese del espejo eres tú. Y eres tú. Pero no hay nadien. Yo creo que, en vista de la perplejidad del lector, el autor intenta explicarnoslo algunos renglones después: "Alguien es cualquier rostro sin nombre que cruzamos por la calle: una cierta prisa, un aire distraido - esa forma peculiar que tiene cada cual de acompañarse, de llevarse a sí mismo de la mano. Eso es alguien: el fotograma de un desconocido en la pantalla-alguien que es alguien porque no está, porque es como si estuviera....Así te ves ahora en el espejo, como negándote desde el exterior. Puedes gritar tu nombre si quieres, y ni aún así te reconocerás - tan frío es todo. $Y$, sin embargo, lo que durante años has tomado por tu rostro verdadero, ¿qué era sino apenas los ecos de un nombre en la memoria? Lo que querías ver reflejado en tus facciones era el recuerdo de tantas voces como te han llamado: imperiosamente, con amor, con desprecio, en la oscuridad, nombrado en falso.... Era eso lo que eras - y no este silencio de ahora en el espejon.

Nos encontramos, pues, frente a esta variación de uno mismo, tan persistente en la creación literaria, en la que de nuevo nos topamos con los versos de Pessoa:

"Si canto lo que no miente

y lloro lo quie pasó,

es que olvidé lo que siento

$y$ creo que no soy yon. 
Y, sin embargo, la identidad no se define, la solución del enigma es otro enigma. Para Lévi-Strauss la crisis de la identidad es el nuevo mal del siglo. De la siguiente manera lo expresaba: "Cuando las costumbres seculares se derrumban, cuando los géneros de vida, cuando las viejas solidaridades se deshacen, puede ocurrir, con toda seguridad, una crisis de identidad... La voluntad sistemática de identificación al otro va a la par de un rechazo obstinado de la propia identificación...., un cuestionamiento de la tautología insustancial del Yo soy yo". En efecto, desde que Platón, en el diálogo "Cratilo", se dedicó a estudiar el significado de las palabras hasta nuestros días, pocas habrán dado más juego que las de ser, individuo, hombre, alma, mente...A ellas tenemos que añadir las que nos ha recordado Ana Maria Matute, hace muy pocos dias, cuando dice: "La palabra hermano, la palabra miedo, la palabra amor, son palabras muy simples, pero llevan el mundo entero dentro de sí. No siempre es fácil, ni sencillo, descubrirlo. Hay que intentar alcanzar el oculto resplandor de esas palabras, de todas las palabras, o de una sola que todavía nadie oyó nunca pronunciar". Tanto que la antropología moderna nos asegura que el hombre es el único ser que es problema para sí mismo, que sabe trocar su esencia en problema. Problema que muchos hombres se habrán planteado más de una vez: ¿qué es lo que hace al ser humano dueño de una vida mental llena de emociones y esperanzas?, de una vida tan diferente de la de un arbusto, un insecto o un rumiante; dueño de una vida distinta de la de todos los demás, incluso de la de todos los demás de su misma especie.

Si los progresos de la biología molecular -los antígenos de histocompatibilidad, la transducción de las señales, las redes neurales, etc.- están sirviendo en la actualidad a la mejor comprensión de la naturaleza del universo y de la condición del hombre, no debemos ignorar la interpretación de la naturaleza que trasciende a la creación literaria. Y yo quiero ver, otra vez, en los versos de Pessoa, la idea de la heterogeneidad del ser, de la unicidad de uno mismo, soportada por los antígenos de histocompatibilidad. Pudiera ser en estos versos:

\section{"Viven en nosotros innúmeros; \\ si pienso o siento, ignoro \\ quien es que piensa o siente. \\ Soy tan sólo el lugar \\ donde se siente o piensa.}

Tengo más almas que una.

Hay más yos que yo mismo. 


\section{Los Argumentos de la Ciencia en la Creacion Literaria}

No obstante, existo.

Indiferente a todos.

Los hago callar: yo hablon.

La creación literaria, desde la Antigüedad hasta Kafka y desde Kafka hasta hoy, ha sido rica en ficciones y metamorfosis de la identidad. La narración es, efectivamente, un terreno apto en especial para cualquier trama en la que se enredan lo temas de la identidad y de la identificación. Y la investigación literaria se ha ocupado tradicionalmente de descubrir y clasificar los entresijos de la ficción, entre los que se cuentan múltiples cuestiones filosófico-lingüísticas, tales como las relaciones entre ver y decir, mostrar y contar.

Hay un cuento de Cortázar que comienza: «Hubo un tiempo en que yo pensaba mucho en los axolotl. Iba a verlos al acuario del "Jardin des Plantes" y me quedaba horas mirándolos, observando su inmovilidad, sus oscuros movimientos. Ahora soy un axolotlm. Desde el comienzo, el narrador confiesa su extravagante identidad. La identidad consiste en apropiarse de la identidad de otro. La atenta observación da lugar a la adopción de la nueva identidad, a la que puede no sea ajena la presencia de la misma voz indígena: "Soy un axolotl». Por la observación, el narrador se transforma, se fija, y, al fijarse, el observador se cambia y se desplaza. El narrador traspasa espacios y traspasa especies. "La absoluta falta de semejanza de los axolotl con el ser humano me probó que mi reconocimiento era válido, que no me apoyaba en analogías fáciles", aseguró el narrador. ¿Cómo se produjo el cambio de identidad?. Tras la primera visita al Jardin des Plantes, continúa el cuento: "....volví al dia siguiente. Empecé a ir todas las mañanas, a veces de mañana y de tarde. Me apoyaba en la barra de hierro que bordea los acuarios y me ponía a mirarlos...Había nueve ejemplares, y la mayoría apoyaba la cabeza contra el cristal, mirando con sus ojos de oro a los que se acercaban. Turbado, casi avergonzado, sentí como una impudicia asomarme a esas figuras silenciosas e inmóviles, aglomeradas en el fondo del acuario. Aislé mentalmente una, situada a la derecha y algo separada de las otras, para estudiarla mejor...Y entonces descubrí sus ojos, su cara. Un rostro inexpresivo, sin otro rasgo que los ojos, dos orificios como cabezas de alfiler, enteramente de un oro transparente, carentes de toda vida pero mirando, dejándose penetrar por mi mirada que parecía pasar a través del punto áureo y perderse en un diáfano misterio interior....El tiempo se siente menos si nos estamos quietos. Fue su quietud lo que me hizo inclinarme fascinado la primera vez que vi a los axolotl». Observador y observado, el na- 
rrador se queda quieto, dia tras dia, repitiendo un gesto, cumpliendo un rito. Y en esa ceremonia puntual de encontrarse consigo, continúa: "Los ojos de los axolotl me decían de la presencia de una vida diferente, de otra manera de mirar...Su mirada ciega, el diminuto disco de oro inexpresivo y sin embargo terriblemente lúcido, me penetraba como un mensaje: Sálvanos, sálvanos. Me sosprendía musitando palabras de consuelo, transmitiendo pueriles esperanzas...No se daban cuenta de que eran ellos los que me devoraban lentamente por los ojos, en un canibalismo de oro...Llegué a ir todos los días, y de noche los imaginaba...eso tenía que ocurrir. Cada mañana, al inclinarme sobre el acuario, el reconocimiento era mayor... Sin transición, sin sorpresa, ví mi cara contra el vidrio, en vez del axolotl ví mi cara contra el vidrio, la ví fuera del acuario, la ví del otro lado del vidrio...Afuera, mi cara volvía a acercarse al vidrio, veía mi boca de labios apretados por el esfuerzo de comprender a los axolotl. Yo era un axolotl...el horror venía -lo supe en el mismo momento-de creerme prisionero en un cuerpo de axolotl, transmigrado a el con mi pensamiento de hombre, enterrado vivo en un axolotl, condenado a moverme lúcidamente entre cristuras insensibles...Ayer lo ví, me miró largo rato y se fue bruscamente...Y en esta soledad final a la que el ya no vuelve, me consuela pensar que acaso va a escribir sobre nosotros, creyendo imaginar un cuento va a escribir todo esto sobre los axolotl».

Es muy posible que el protagonista del cuento de Cortázar fuera diagnosticado de parafrenia, o delirio de imaginación. Algo más graves me parecen los síntomas que revelan los protagonistas de "El beso de la mujer araña", de Manuel Puig, que, con una especie de psicosis alucinatoria crónica, origina toda una colección de especies cruzadas en el interior de una celda a cargo de un homosexual y un terrorista. Molina, apellido de hombre, nombre de mujer. Valentín, colaboracionista o resistente, guerrillero o cómplice, cobarde o valiente. Tanto el cuento de Cortazar como esta novela acuden al encierro, al acuario o a la celda, para el diseño psicológico de la identidad. Los híbridos hombre-Dios, hombre-animal, hombre-mujer, hombre-niño, son especialmente aptos para las metamorfosis, para la apropiación de la identidad de otro, para la creación de un espacio en que identidad-alteridad no se distinguen. Umberto Eco ha recordaddo que "los Antiguos ya sabian que cualquier cosa es susceptible de parecerse a otra si se la hace objeto de cierta descripción". Y en "El beso de la mujer arañan, la ficción se multiplica; la narración abarca la narración de películas, hay algo así como un montaje en el que el ámbito físico y del lenguaje de la celda carcelaria, por el hecho de la narración de una película, se extiende a otros espacios y a otros lenguajes: diálogos, 


\section{Los Argumentos de la Ciencia en la Creacion Literaria}

monólogos, informes policiales y periodísticos, actas de procesamiento, narraciones psicológicas, etc. Son de esta novela los siguientes párrafos: "Es una mujer vistosa, al primer vistazo, pero enseguida después se le nota algo rarísimo en la cara, algo que da miedo y no se sabe qué es. Porque es una cara de mujer pero también una cara de gato. Los ojos para arriba, y raros, no se como decirte, el blanco del ojo no lo tiene, el ojo es todo color verde, con la pupila negra en el centro y nada más....Ella tiembla, de frio o de miedo, aunque los rugidos parecen haberse aplacado. Ella dice, apenas en su susurro, que tiene miedo de ir a su casa y pasar la noche sola. Van al departamento de el....Ella no se anima a mirarlo en los ojos, coloca la cabeza sobre las rodillas de el. Entonces empieza a contar que había una leyenda terrible en su aldea de la montaña, que siempre la ha aterrorizado desde chica. Y eso yo no me acuerdo bien como era, algo de la Edad Media, que una vez esas aldeas quedaron aisladas por la nieve meses y meses, y se morian de hambre, y que todos los hombres se habian ido a la guerra, algo así, y las fieras del bosque llegaban ambrientas hasta las casas, no me acuerdo bien, y el diablo se apareció y pidió que saliera una mujer si querían que el les trajese comida, y salió una mujer, la más valiente, y el diablo tenía al lado una pantera hambrienta enfurecida, y esa mujer hizo un pacto con el diablo, para no morir, y no se que pasó y la mujer tuvo una hija con cara de gata. Y cuando volvieron los cruzados de la Guerra Santa, el soldado que estaba casado con esa mujer entró en la casa y cuando la fue a besar ella lo despedazó vivo como una pantera lo hubiese hecho....Y siguieron naciendo en la montaña mujeres pantera.... Y la leyenda es que la raza de mujeres pantera no se acabó y están escondidas en algún lugar del mundo, y parecen mujeres normales, pero si un hombre las besa se pueden transformar en una bestia salvajen.

Cuando, como acabamos de ver, la literatura participa del tema de la identidad, conocer y confundir, describir oposiciones y contrarios, toman parte en los discursos de ficción. A este propósito, el filósofo francés Jacques Derrida se preguntaba: "¿Qué es saber? Saber es identificar o, más todavía, reducir a lo idéntico.

Identificar es buscar la identidad, resolver las ficciones de la dualidad que la identidad plantea. Pocos planteamientos en busca de la identidad con la trascendencia de los involucrados en el Derecho como valor de orden, norma y justicia; los que, a la vez, gozan de la dimensión que tiene presente las repercusiones sociales de la norma. Repercusiones sociales, tan de nuestros días, de las que ya se hizo eco Cervantes, en el coloquio 
entre Cipión y Berganza, en estos renglones: "...ni soy ni he sido hechicera en mi vida; $y$ si he tenido fama de haberlo sido, merced a los testigos falsos y a la ley del encaje, y al juez arrojadizo y mal informado, ya sabe todo el mundo la vida que hago en penitencia....".

No podríamos concluir esta correría a través de la literatura utilizando los descansaderos que nos han brindado los argumentos de la ciencia, sin asomarnos al mundo, a ese mundo de los sentidos tal y como nos lo describe Diane Ackerman, autora del interesante libro "Una historia natural de los sentidos", en el párrafo: "Nos agrada pensar que somos criaturas magnificamente evolucionadas, con nuestro traje y corbata, gente que vive a muchos milenios y muchas circunvoluciones mentales de distancia de la caverna, pero nuestros cuerpos no están tan convencidos de ello. Podemos darnos el lujo de estar en la cima de la cadena alimentaria, pero nuestra adrenalina sigue fluyendo cuando nos enfrentamos con predadores reales o imaginarios. Incluso alimentamos ese miedo primordial yendo a ver peliculas de monstruos. Seguimos marcando nuestro territorio, aunque ahora a veces lo hacemos con ondas de radio. Seguimos luchando por la posición y el poder. Seguimos creando obras de arte para realzar nuestros sentidos y sumar más sensaciones aún al mundo ya lleno de ellas, de modo que podamos anegarnos en el lujo inagotable de los espectáculos de la vida. Seguimos aferrándonos con doloroso orgullo al amor, el sexo, la lealtad y la pasión. Y seguimos percibiendo el mundo, en toda su móvil belleza y su terror, allí mismo, en el latir del pulso. No hay otro modo. Para empezar a entender la magnifica fiebre que es la conciencia, debemos tratar de entender los sentidos: cómo evolucionan, cómo pueden expandirse, cuáles son sus límites, a cuáles hemos puesto un tabú, y qué pueden enseñarnos sobre el fascinante mundo que tenemos el privilegio de habitar». $\mathrm{Y}$, en otro lugar, la autora nos incita a volver a sentir las texturas de la vida $\mathrm{y}$, frente al esfuerzo de la vida moderna por apartarnos de esas texturas y despojarnos de la exquisitez sensorial, nos brinda el ejemplo maravilloso de cómo "uno de los grandes sensoriales de todos los tiempos no fue Cleopatra, ni Marilyn Monroe, ni Proust, ni ningún otro de los voluptuosos clásicos, sino una mujer ciega, sorda y muda. Helen Keller tenía sus restantes sentidos tan finamente sintonizados que, cuando ponía las manos sobre la radio para gozar de la música, podía captar la diferencia entre los bronces y las cuerdas. Escuchaba las coloridas y nostálgicas historias de la vida a lo largo del Mississippi de los labios de su amigo Mark Twain. Escribió extensamente sobre los aromas, gustos, texturas y sensaciones de la vida; que exploró con la voluptuosidad de una cortesana....pocas personas de su generación tuvieron una vida tan plena como la suya". 


\section{Los Argumentos de la Ciencia en la Creacion Literaria}

No tiene, pues, nada de extraño que en la "Dióptrica" de Descartes los fenómenos de la vista aparezcan referidos a los del tacto, y las ilustraciones de la óptica se sustituyan por figuras de hombres tratando de obtener con bastones las perspectivas de los objetos. Ante la incuestionable grandeza de este sentido, Dámaso Alonso compuso un breve poema titulado "Gozo del tacto":
Estoy vivo y toco.
pues mañana es cierto
Toco, toco, toco. que ya estarás muerto,
Y no, no estoy loco. tieso, hinchado, yerto.
Hombre, toca, toca
Toca, toca, toca,
lo que te provoca:
seno, pluma, roca, iqué alegría loca! Toca. Toca. Toca.

Este predominio del tacto en la ausencia de la visión forma parte de esa superior interiorización del ciego, que la hace calcular con mayor precisión la sucesión del tiempo por la secuencia de acciones y pensamientos; o percibir con finura extrema el sentido de la suavidad de la piel, la compacidad de las carnes, la dulzura del aliento, los encantos de la voz y la pronunciación.

Quizá la verdadera situación del tacto nos la narra Galdós en «Marianelan. Cuando el acomodado Sr.Golfín dudaba de la exactitud del itinerario, atravesando ríos y praderas, en busca de las famosas minas de Socartes, se preguntó ¿por qué no hay gente en estos lugares? oyó primero el violento ladrar de un perro y luego la dura voz de un hombre que gritaba: ¡Choto, Choto, ven aquí! El dueño del perro grande y negro logró hacerse con el animal una vez que este hubo olisqueado al bien parecido Sr.Golfín. el dueño resultó ser un misterioso jóven que, inmóvil y rígido, se dispuso a mostrar al viajero las veredas y taludes para atajar el camino a las minas. Tras los primeros momentos de sorpresa, la conversación se inicia inevitablemente: "Sí, señor, soy ciego; pero sin vista se recorrer de un cabo a otro las minas de Socartes. El palo que uso me impide tropezar, y Choto me acompaña, cuando no lo hace la Nela, que es mi lazarillo. Conque sígame usted y déjese llevarn. Y a nueva pregunta, medio compasiva medio interesada, del viajero, contestó el guía: «Sí, señor, de nacimiento. No conozco el mundo más que por el pensamiento, el tacto y el oído. He podido comprender que la parte más maravillosa del universo es esa que me está vedada. Yo se que los ojos de los demás no son como estos mios, sino que por sí conocen las cosas; pero este don me parece tan extraordinario que ni siquiera comprendo la posibilidad de poseerlo". 
Aparte de la idea de privación de la vista, ciego significa que algo procede sin discernimiento o reflexión - confianza ciega, codicia ciega-; o todo aquello en que no hay camino ni rumbo, como en el verso de Virgilio, en "Las Geórgicas": "Tardo en la ciega noche, el mar turbado". De la misma manera se significa la posesión vehemente de algún atributo. Y, así, se habla de cómo son ciegos, el despecho y el amor, el error y la pasión, la obediencia y la suerte, el apetito y la fortuna. Y ¡cómo no!, la sabiduría refranera lo recuerda. Pues si "el ciego y el sabio yerran un paso", no cabe duda de que «si el ciego de amores muere, ¿qué hará quien vista tuviere?" A su lado, los ojos han sido siempre símbolơ de la hermosura, la belleza y la piedad. Quizá por ello decían los antiguos que el mirar de Júpiter era hacer misericordias; y por ello, también a los ojos hacemos referencia cuando sublimamos la guarda y el amor.

Todo ello no es sino un anticipo de la intensa participación de la ceguera y de los ciegos en el fenómeno literario. Fenómeno literario que ha recogido la múltiple participación de la ceguera en la picaresca, la marginación, el arte y la vida intelectual, la sencillez y la alegría estudiantil, e, incluso, sobre la misma contemplación y el juego alegórico.

Si tanto la ciencia como la poesía son instrumentos de descubrimiento y de creación; ambas revelan, en efecto, esta parte maravillosa del universo. Como la que revela Dámaso Alonso en "Los gozos de la vistan:
Yo digo
"forma". Y ellos extienden en silencio las manos sarmentosas, $y$ palpan con amor: tiernamente intuyen, "ven" a su manera. Yo les digo "perspectiva", "relieve", y acarician los planos de las mesas, o siguen las paredes, $y$ tocan largamente la esquina. Se sonrien, comprenden algo. Pero si digo «luz», se quedan absortos, inclinan la cabeza, vencidos: no me entienden".

Si la literatura exalta en la creación poética la imagen del mundo sumergida en la luz y cómo ambas -imagen y luz- se perciben por el ojo y la visión; también la literatura nos sitúa en la huella de la realidad, nos descubre las reláciones de la invidencia con el entorno social y cultural.

A este respecto, sucedió que a un moderno internado para jóvenes de ambos sexos llegó un nuevo alumno que desconocía quienes y cómo eran 


\section{Los Argumentos de la Ciencia en la Creacion Literaria}

sus compañeros que se encontraban charlando en una sala de estar. Al entrar en la sala Ignacio, el nuevo residente, una de las muchachas, Juana, salta de pronto:

Me ha cogido de la mano.......No le conozco.

$\mathrm{Y}$ uno de los chicos, Andrés, le pregunta:

¿Qué buscas aquí?

Nada. Dejadme. Yo....soy un pobre ciego, contestó Ignacio, el nuevo.

¿Qué has dicho que eres?, insistió la pregunta;

Un ciego, insistió la respuesta.

$\mathrm{Y}$, en medio del regocijo general, otro de los antiguos, Miguel, parecería que intenta burlarse del pobre Ignacio al continuar con la interrogación:

¿Quiere que le pase a la otra acera?

Cuando, en realidad, todos los muchachos están pensando que el burlador es, de verdad, el nuevo residente, Ignacio; este exclama:

Pero, ¿es qué no lo veis?

Efectivamente; nadie lo veía; todos -el nuevo y los antiguos-, todos eran ciegos. A muy grandes rasgos este es el comienzo de la obra de Buero Vallejo "En la ardiente oscuridad".

El padre de Ignacio dudaba si dejar a su hijo, o no, en el internado; le parecía tan fácil una desgracia, un accidente.... cuando intervino el director, Don Pablo, también ciego: podemos llegar donde llegue cualquiera. Ocupamos empleos...somos fuertes, saludables, sociables, poseemos una moral de acero, y no son estas las conversaciones a las que ellos estén acostumbrados.

Ignacio, al fin, se quedó, y entró en la vida oscura y ardiente, a la vez, de los chicos y las chicas ciegos; y entró en los estudios, las bromas, los celos y los amores....con más reticencia que camaradería. Al fin y al cabo, Ignacio es hijo único, y entre las muchachas comentan:

-Este Ignacio tiene algo indefinible que me repele ¿̇Tú crees en el fluido magnético?

- Sí, mujer ¿Quién de nosotros no?

- ${ }^{\circ}$ Muchos aseguran que eso es falso

- Muchos tontos....que no están enamorados. 


\section{Ángel Martín Municio}

Al final, Ignacio muere ¿en accidente?, ¿a manos de los celos de algun compañero? Como quiera que ello fuere, Ignacio no se acomodó ni al gozo ni al consuelo de sus compañeros. Algunas de sus frases dirigidas a ellos lo revelan:

- No teneis derecho a vivir, porque os empeñais en no sufrir... fingiendo una normalidad que no existe...

- No puedo conformarme iY menos sonreir! Y resignarme con vuestra estúpida alegría de ciegos...

- ¡El amor entre nosotros no pasa de ser una triste parodia del de los videntes! Porque ellos poseen al ser amado por entero. Son capaces de englobarle en una mirada. Nosotros poseemos... a pedazos. En realidad no nos amamos. Nos compadecemos y tratamos de disfrazar esa triste piedad con alegres tonterías.

Frente a la oscuridad atormentada de Ignacio, en la obra de Buero, se configura la imagen intelectual de Max Estrella, escritor ciego, grandilocuente e hiperbólico, en la literatura del esperpento de don Ramón del Valle-Inclán. En una ocasión en que bromeaba con su mujer Collet de que había recuperado la vista, ella le pregunta ipero qué ves?; el mundo, respondió Max. ¿A mi me ves? arguyó Collet. ¡Las cosas que toco, para qué necesito verlas!, fue la contestación. En esta respuesta, más que la dualidad de los sentidos, intentaba Max sacar a relucir su ingenio, como cuando en una taberna participa en un jaleo con Enriqueta, mozuela golfa, revenida de un ojo, y dirigiéndose a a don Latino le dice: "iLatino! Préstame tus ojos para ver a la Marquesa del Tango! O como cuando, en una visita al Ministro de la Gobernación, y en respuesta al comentario de este: "Una ceguera accidental, supongo...", contestó Max: "Definitiva e irrevocable. Es el regalo de Venus".

Frente a estas dos actitudes psicológicas, diametralmente opuestas: la de la inadaptación total y la de la supervivencia jocosa, Buero nos muestra en "El concierto de San Ovidio" la permanente lección de la tragedia en clave de parábola. Y es así cómo David, líder de una orquestina de ciegos, se enfrenta a su empresario, tan eficaz como vacío de moral, que disfraza su codicia con la careta de la filantropía; trampa en la que caen porque se les ofrece una olla, algo más sabrosa que la de los ciegos.

"Hay que convencer a los que ven de que somos hombres como ellos, no animales enfermos", dijo David a sus temerosos compañeros de orquestina, en su permanente intento de desenmascarar al negociante sin escrúpulos. 


\section{Los Argumentos de la Ciencia en la Creacion Literaria}

Dos de ellos, Elías y Lucas, evocan la desesperanza colectiva, la sensación de no tener pasado ni forma de salir hacia el futuro en su vida individualizada:

¡Nunca hubo orquestas de ciegos!

¡Ni las habrá! respondió Lucas,

¡No servimos para nada!, continuó Elías.

Cuando intervino el empresario: Pero....vosotros żamáis? Lo que espoleó la clara superioridad moral de David, capaz de transformar sus movimientos temerosos y su torpeza física en el desafio a Adriana: ;Conozco este camino mejor que tu. Puedo andarlo sin luz!. Desafio frente a la oscuridad; desafio frente a las actitudes, cuando Adriana reta a la esperanza personal y colectiva de David; y, cuando triunfante el amor, exclama: jPero, nuestros hijos verán!

Esta seguridad desafiante del ciego David en ese jPuedo andarlo sin luz! tiene semejanzas en otras narraciones literarias, como en la novela de Alvaro Cunqueiro "Cuando el viejo Sinbad vuelva a las Islas". En ella, el ciego Abdalá exclamaba:

"jLlévame de vigía, Sinbad!, ¡No te lo digo por burla!

A tientas lo conozco todo, hasta si el vino tiene

agua, y por el oído se donde rompe el mar.

¡Aún sirvo para algo, Sinbad!

La literatura nos recuerda también al ciego, no como sustrato de acontecimientos psicológicos especiales o de lucha por el predominio de alguno de los sentidos, sino como mendicantes y vagos. El protagonista de "Misericordia", de Galdós, el moro ciego Almudena, aún pidiendo limosna en el Oratorio de Caballero de Gracia, era un ejecutivo de la mendicidad, sobre cuya tecnología y rendimientos vociferaba. Usurero de la pobreza, a el acudían sus colegas de necesidades para lograr algún que otro préstamo: Y, así, la señora Benigna le pidió una vez un duro y Almudena -relata la novela- volvió a ella su rostro, y hasta podría decirse que la miró, si mirar es dirigir los ojos hacia un objeto, poniendo en ellos ya que no la vista, la intención, y en cierto modo la atención, tan sostenida como ineficaz. Y, para conversar sobre las posibilidades y condiciones del crédito, ambos se sentaron en la plaza del Progreso para poder hacerlo con tranquilidad.

Entre las emotivas fantasías que tienen a los ojos como protagonistas, "El jugador de sus ojos" de Filgueira Valverde, y el cuento del peruano Clemente Palma, titulado "Los ojos de Lina». Lina tenía los ojos más ex- 
trañamente endiablados del mundo. Lina llegó a ser la mujer de Jym, un oficial de la marina inglesa que, en cierta ocasión, contó su encuentro y su vida:

"Axelina o LINA tenía dieciseis años y yo, loco de amor por ella, profesaba a sus ojos el odio más rabioso que puede caber en un corazón de hombre. Cuando Lina fijaba sus ojos en los mios, me desesperaba, me sentía inquieto y con los nervios crispados; me parecía que alguien me vaciaba una caja de alfileres en el cerebro y que se esparcían a lo largo de mi espina dorsalm.

La narración se extiende en estas especiales sensaciones e inexplicable fenómeno que no hacía sino sonreir a cuantos médicos y expertos consultaba. "Y lo peor es que yo adoraba a Lina-sigue asegurando el teniente Jym-con exasperación, con locura, a pesar del efecto desastroso que me producían sus ojos". Que si la tensión álgida del sistema nervioso, que si alteraciones psíquicas, que si trasfondo histérico; pero cuando Lina tenía alguna preocupación, Jym veía pasar por sus pupilas las ideas bajo la forma vaga de pequeñas sombras fugitivas coronadas por puntitos de luz. He dicho sombras -aclaró Jym-porque es la palabra que más se acerca. Salían por detrás de la esclerótica, cruzaban la pupila y al llegar a la retina destellaban, y entonces sentía yo que en el fondo de mi cerebro respondía una dolorosa vibración de las células, surgiendo a su vez una idea dentro de mí. El teniente, sin embargo, se esforzaba en interpretar la mirada y los ojos de Lina, que, claro, tenían un color; un color que ni todos los oculistas del mundo, ni todos los pintores habrian acertado a determinarlo ni a reproducirlo. Estos eran los ojos de Lina cerrados o entornados; pero, una vez abiertos y lucientes las pupilas jallí de mis angustias!. El enamorado teniente llegó a traducir los estados psíquicos de Lina, sus irritaciones y placeres, todos los juegos de su espíritu, a través de las múltiples tonalidadaes de sus ojos: los sentimientos románticos eran verdes; las alegrías violáceas; amarillos los celos y sus pasiones rojas. En vano podía el tratar de resistir; y, así, se expresaba en distintos lugares de la relación: sentía mi dignidad de varón humillada....; mi mecanismo nervioso llegaba a torsiones desgarradoras....; mi cerebro saltaba dentro de mi cabeza....;me arrancaban el alma para triturarla....; la obsesión de los ojos de ella me resultaba insoportable. De noche los veía fulgurar; o incrustados en la pared, terribles y porfiados; adheridos sobre mis párpados con tenacidad.

A pesar de todos estos influjos, Lina no se había percatado de su autoría hasta que, próxima la boda, en una ocasión tuvo Jym que cerrar los 


\section{Los Argumentos de la Ciencia en la Creacion Literaria}

ojos casi desvanecido por la cercanía de los de Lina. Y surge entonces la conversación central de la historia:

¡Cierra los ojos, Lina mia, te lo ruego! Lina que, sorprendida e inquieta, los abría más y más.

¿Qué tienes, estaas enfermo? ¡No, nada tengo!

¡Mientes, algo te pasa! ¿Y, por qué querías que cerrara los ojos?, ¿No quieres que te mire?

¡Tu has hecho algo malo! ¡Te lo conoceré en los ojos, mírame!

Tuve que cerrar los ojos y la besé en la frente iLina, déjame! ¡No me beses! Mirame ¿̇por qué no me miras?

El no se atrevió sino a callar, aunque se respondía para sus adentros: No te miro porque tus ojos me asesinan.

Faltaban pocos días para la boda; ella enfermó durante un mes sin que nadie, tampoco el novio Jym, pudiera verla. Al fin, Jym visitó a Lina en su habitación....estaba en una oscura penumbra....rodeada de vestidos, regalos, collares y zarcillos ....Ella le ofreció su regalo....era una cajita de cristal de roca, forrada de terciopelo rojo....Lina, trémula le ofreció la cajita, mientras aseguraba: "iMírala a la luz, son piedras preciosas, cuyo brillo conviene apreciar debidamente iEs mi regalo de boda! Ella misma abrió una hoja de la ventana para que el novio enamorado valorase el compromiso. En el lugar de aquellos ojos vencedores y ardientes, otros negros, vidriosos e inmóviles, en unas cuencas que dibujaban una sonrisa entre amorosa e irónica. En la cajita de cristal de roca, aquellos ojos que, amenazadores y burlones, seguían con la misma mirada endiablada de siempre.

Esta historia no puede sino recordar las relaciones fisiopatológicas ojos-cerebro-visión, que en la época moderna van desde las teorías de la visión de Newton y Berkeley, a comienzos del siglo XVIII, hasta los conocimientos moleculares de hoy sobre la fotorrecepción y la transducción de señales. Y, así, parecía ver en los ojos de Lina una especie de hiperactivación de la rodopsina y una mediación exaltada de las proteínas de membrana para dejar permanentemente abiertos los canales de las células de la retina.

Pero, todo ello habían de ser imágenes a los ojos de Jym, que las procesaba en su cerebro de esta manera tan singular. Tan singular que logró hacer verdad; verdad en la historia de amor del cuento; en aquel soneto de Unamuno "Ojos sin luz»: 


\section{Ángel Martín Municio}

Hermosos ojos que no veis, topacios de lumbre muerta, cristalinas, lunas gemelas tristes, vais por los espacios tenebrosos mecidas como cunas

de invisibles visiones y de agüeros de un mundo que marrara. Y de tiniebla se abren ante vosotros los senderos que van rompiendo de la luz de la niebla.

Hermosos ojos que no veis, se mira el ángel de la luz en vuestro brillo, un soplo inmaterial triste suspira,

alza vista sin ojos al castillo de Dios, y entona luego con su lira aquel de eterno Amor dulce estribillo. 